\title{
長期設計荷重下における $\mathrm{RC}$ 造スラブの鉄筋の 抜出しに関する解析的研究
}

\section{はじめに}

長期持続荷重下でひび割れを生じた両端固定鉄筋コン クリート（以下， $\mathrm{RC}$ と略）造スラブの長期たわみに及 ぼす影響として，固定端からのスラ.ブ端部引張鉄筋の経 時的な抜出しは1が無視できないほど大きいことが既往 の実験資料の蓄積から明らかにされている。この端部引 張鉄筋の経時的な抜出しは鉄筋とその周囲のコンクリー 卜との付着応力一寸べり関係における付着剛性の経時的 低下，すなわち，付着クリープに州因するものであるこ とが定性的に分ってきており，これを何らかの方法で考 慮すると長期たわみの計算結果が実験結果によりよく近 似することが示されている。

そこで,この種の研究の焦点は端部引張鉄筋の経時的 抜出しをどのように定量的に評価するかにかかってくる が,これについては，現在，2つの算定方法が示されて いる。

一つは小森博士等による算定方法 ${ }^{11}$ で，鉄筋の加力端 応力とは別途に日本建築学会 $\mathrm{RC}$ 計算規準に準じて平 均付着応力を与え，また鉄筋の応力分布を直線状に仮定 して定着長を計算し，しかる後鉄筋の抜出し量を求める ものである。この算定方法は土橋博士・井野博士・杉野 目氏の研究 ${ }^{21} に も$ 利用されている。この算定方法では コンクリートのクリープ，乾燥収縮，および鉄筋とコン クリート間の付着クリープを考慮していないため, 端部 引張鉄筋の抜出しの経時変化を表すことができないとい う久点がある。即ち，この算定方法を用いた端部引張鉄 筋の抜出しは，端部引張鉄筋応力を一定とすると，経時 変化に関係なく一定となる。そこで，この算定方法を長 期たわみ計算に適用するに当たり，端部引張鉄筋の応力 を経時的に大きく増大させて端部引張鉄筋の抜出しによ るたわみを計算してこれを長期たわみの一成分として扱 うが， あるいは端部引張鉄筋の応力を一定として端部 引張鉄筋の抜出しによるたわみを計算しこれを瞬時たわ みに付加して瞬時たわみの一成分として扱う方法"肪と られている。本来, 平均付着応力を含めて付着応力の大

本研究の一部は昭和 63 年日本建築学会九州支部研究報告 ${ }^{(4)}$ で発表した。

* 熊本工業大学 助教授 $\cdot$ 工博

(1988 年5月10 日原稿受理, 1989 年 3 月 13 日採用決定)
正会崱岩 原昭次*

きさは付着剛性と引張鉄筋の応力の大きさ等の相関で決 まるものであるが，この算定方法ではこれらに関係なく 定められており，平均付着応力の扱い方にあいまいさを 残している。

もう一つは小柳博士によって提案されている31もの で，片引き試験体の付着に関する長期持続載荷実験から 得られた㬰験結果を基にして引張鉄筋の経時的な抜出し 量を実験式で直接評価する方法である。この方法では小 森等の算定方法における矛盾（引張鉄筋応力を一定亡す ると鉄筋の抜出しは起こらない）を実験結果を利用する ことによって解消しているものの，前述のコンクリート のクリープ，乾燥収縮および付着クリープと鉄筋の抜出 しとの相関関係が不明確のままとなっている。

上記 $2 つ の$ 算定方法は，いずれにしても，付着応力一 すべり関係が最大要因である付着応力問題における経時 的な力学的メカニズムに及んだ結果とはなっていない。

本研究は, 以上の研究手法とは異なり, 付着応力一す ベり関係の基本式から出発し、コンクリートのクリープ, 乾燥収縮および付着クリープを考慮した，経時的な引張 鉄筋の抜出しに関する解析的定式化を図り，その妥当性 を検討するとともにその結果を踏まえ，長期持続設計荷 重下における鉄筋の抜出しの算定式を示すものである。

\section{2. 一軸引張りの経時的付着応力問題の基本}

2-1 記 号

$t:$ 経過日数

$L ：$ 一軸引張りの解析モデルでコンクリート中に 埋込まれた鉄筋の長さ，すなわち，定着長

$\beta f:$ 加力端近くの付着劣化による付着応力消失区 域の長さ $(t \geqq 1)$

$f:$ 異形鉄筋の節間隔

$\beta$ : 付着応力消失区域長さを決めるための倍率 (( 2 ) 式)

$l$ : 鉄筋の有効定着長（有効な定着域の長さ）（ $t$ $=0$ で $L, t \geqq 1$ で $L-\beta f$ )

$a$ : 有効定着域 $l$ における弾塑性境界位置

$\phi_{t}:$ コンクリートのクリープ係数

$\epsilon_{s h}:$ コンクリートの乾燥収縮歪

$E_{c}:$ コンクリートのヤング係数 
$E_{t}:=E_{c} /\left(1+\varphi_{t}\right)$

$E_{s}:$ 鉄筋のヤング係数

$n:$ ヤング係数比 $\left(=E_{s} / E_{t}\right)$

$S, \tau:$ 任意位置の相対すべり量, 付着応力

$S_{y}, \tau_{y}$ : 降伏時相対すべり量, 付着強度

$\sigma_{s}:$ 任意位置の鉄筋応力

$\sigma_{s 0}$ : 有効定着域において $x=0$ の位置の鉄筋応力

$\sigma_{\mathrm{c}}:$ 任意位置のコンクリート応力

$\sigma_{\mathrm{c} 0}$ ：有効定着域において $x=0$ 位置のコンクリー 卜応力

$S_{e}, S_{p}$ : 弾性域，塑性域各々における相対すべり量

$\sigma_{s e}, \sigma_{s p}$ ：弾性域，塑性域各々における鉄筋応力

$S_{0}$ ：有効定着域で $x=0$ の位置における相対すべ り量

$S_{w}$ : 鉄筋の抜出し量（鉄筋がコンクリートに埋込 まれている位置の相対すべり量）

$\tau_{a}$ : 弾塑性境界位置 $(x=a)$ における付着応力

$K_{0}$ : 初期 $(t=0)$ の弹性付着剛性

$k_{1}:$ 経時的な付着剛性低下率

$K_{t}:=k_{1} K_{0}$

$A_{s}, A_{c}$ : 鉄筋断面積, コンクリート断面積

$p:$ 鉄筋比 $\left(=A_{s} / A_{c}\right)$

$\Psi:$ 鉄筋の周長

2-2 解析モデル

両端固定 RC 造スラブの端部引張鉄筋の抜出しは, 結局のところ，一軸引張りの付着応力問題を解くことに よって得られる。したがって, 解析モデルは一軸引張 $\mathrm{RC}$ 部材であり，両引き試験体モデルに対する解は図一 1 中（a）に示すように左半分について誘導される。片 引き試験体モデルは通常 2 種類の境界状態が考えられる が，ここでは，図一1(b) に示すようなモデルとする。

2-3 仮 定

(1) コンクリートと鉄筋の断面重心軸は一致し，部材 は湾曲しない。

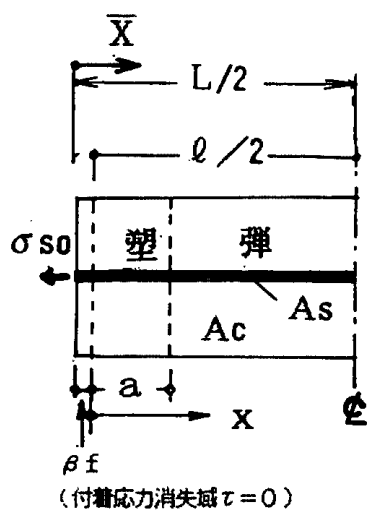

（a）両引き試験体

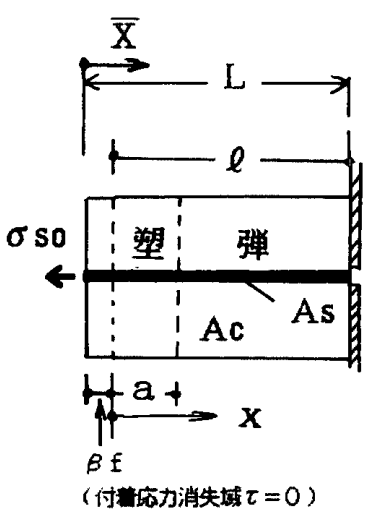

（b ）片引き試験体
図一1 試験体
(2) 軸方向変形のみを考虑し，それと直角方向の変形 を無視する。

(3) コンクリートと鉄筋各々の平均変形の差を相対す ベり量とする。

(4) コンクリート応力と鉄筋応力は各々の断面で均一 に分布する。

(5) コンクリートと鉄筋の各々の応力一堽関係は弾性 とする。

(6) 付着強度は経時的に変化せず一定とする。

(7) 付着応力一すべり関係において，一度塑性域が生 じたならばその区域が広がるこ上があっても，狭ま ることはないとする。また塑性域における付着応力 が経時的に低下してもその分布は均一であるとす る。

(8) 経過日数 1 日以後の加力端近くの付着劣化域は, 解析的にその一部分を付着応力が消失する区間に置 き換え，またその区間長は経時変化に関係污く一定 とする。

(9) 付着応力が消失すると仮定する区域のコンクリー トの影響は無視する。

(10) 付着応力一すべり関係は完全弾塑性上する（図一 $2)$ 。

2-4 経時的な付着剛性

付着クリープという術語自体非常に莫然としている が，ここでは，持続載荷以後の付着応力一寸べり関係に 起因する相対すべりの経時的な現象のこと竧いうものと する。

付着クリープに関する研究は，おそらく，狩野春一。 向井両博士の研究4が少なくとも我が国で最初のものと 考えられる。その後，ここ10 年程の間に幾つ汃の研究 が行われているものの, 付着クリープは定量的にまだよ く分っていないのが実情である。

既往の実験結果 ${ }^{5,6,7,8)}$ から付着クリープは載荷直後か ら経過日数 1 日までの挙動とそれ以後の挙動との $2 つ に$ 区分することができるようである。この区分に従って， 本解析では付着クリープを次のように定式化する。

a ) 載荷直後の付着応力一すべり関係

瞬時載荷実験等の結果による。

b) 経過日数 1 日以後の付着劣化と付着忘力一すべり 関係

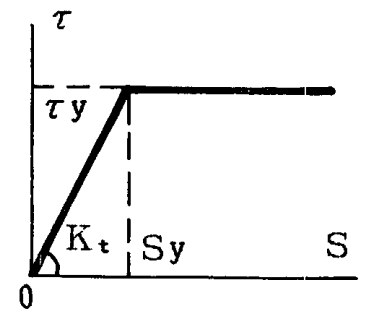

図一2 付着忘力ーすべり関係 
b-1 加力端付近の付着劣化

既往の研究9 によれば，付着応力は加力端から鉄筋直 径の 3〜4 倍の位置で最大となり, 加力端により近い位 置では最大付着応力より低いこと, すなわち, 付着劣化 域は加力端から鉄筋直径の 3 4 倍の範囲にあることが 指摘されている。

また，長期設計レベル（SD 30 の鉄筋に対し，加力端 鉄筋応力 $\left.\sigma_{s 0}=2 \mathrm{tf} / \mathrm{cm}^{2}\right)$ を対象にした持続荷重下での実 験6!によれば，その付着応力分布図から付着劣化域は加 力端から 5 8 cm の範囲と考察できる。丸鋼の場合と 異なり，異形鉄筋を使用している場合の付着劣化はその 節の機械的抵抗作用 ${ }^{101}$ が大きく関係するはずであるか ら，この付着劣化域は鉄筋直径よりも節間隔を基準にし た方がより望ましいと考えられる。そこで, 前述の付着 劣化域を節間隔で表現し直すと, 両者共 D 16 横節の異 形鉄筋であるので，文 8）に対し 5-6 節，文 6) に対し 5〜7節で平均として大略 6 節となる。この付着劣化域 では付着応力がほとんど消失している段階から余り低下 していない段階まで含まれているので，この劣化域にお ける付着応力一すべり関係を一義的にとらえることは非 常に困難である。

したがって解析にあたっては大胆な仮定を設けざるを 得ないが，ここでは文 6)，文 8) を参考にして，加力端 鉄筋応力 $\sigma_{s 0}=2 \mathrm{tf} / \mathrm{cm}^{2}$ の加力レベルで付着劣化域を 6 節とし，そのうち加力端側 $1 / 3$ 部分を付着灾力が消失す る $(\tau=0)$ として扱う区域, 残りの $2 / 3$ 部分の付着応 力は付着劣化域外の付着応力一すべり関係に従うと仮定 する。

付着応力を 0 として扱う範囲（ここでは，付着応力消 失域と称することにする) は加力の大きさに比例すると し，これを次の式で表す。

$$
0 \leqq \bar{x} \leqq \beta f \quad \text { で } \tau=0 \text {. }
$$

ただし， $\bar{x}$ は加力端を基準にした座標

ここで, $f$ は異形鉄筋の節間隔寸法, $\beta$ は加力レベル に応じた倍率で次式である。

$$
\beta=2 \times\left(\sigma_{s 0} / 2 \mathrm{tf}\right)
$$

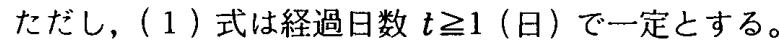
以上の付着応力消失域 $(0 \leqq \bar{x} \leqq \beta f)$, 塑性域 $(0 \leqq x$ $\leqq a ＼mathrm{~ あ る い は ~} \beta f \leqq \bar{x} \leqq(\beta f+a))$ および弾性域を図示 すると，図一1(a)，(b) のようになる。

なお，便宜上，本論文では付着応力消失域と仮定する 以外の区域を有効定着域, その長さを有効定着長（図一 1 中の記号 $l$ ) と称することにする。

b-2 付着応力ーすべり関係

鈴木・大野らの研究によると，文 7）では経過日数 51 日までの実験結果に基づいて，付着剛性は載荷直後から 経過日数 1 日までの間に大きく低下しその後はほとんよ゙ 変化しないという結果を得ている一方で，文8）の別の
実験結果では付着剛性は経過日数約 150 日で載荷直後の ものに対して約 4〜5 割低下したと報告している。載荷 直後から経過日数 1 日間での付着剛性が大きく低下する ことは他の研究5,6)でも明らかであるが，その後の経時 変化については，今のところ実験資料が少なく，低下を 続けるのかあるいは略々一定を保つのかを明らかにでき るまでには至っていないようである。

ここでは，コンクリートのクリープ歪や乾燥収縮歪が クリープ係数で近似的に表示され得ることから類推して 付着剛性の経時変化を, 簡単に, 次式で表されると仮定 する。

$$
\begin{aligned}
& K_{t}=k_{1} K_{0} \\
& k_{1}=\frac{1}{\alpha} \cdot \frac{1}{1+\eta\left(\varphi_{t}-\varphi_{1}\right)} \\
& \left.\begin{array}{l}
(t=0) \\
(t \geqq 1)
\end{array}\right)
\end{aligned}
$$

ただし， $k_{1}$ は $t \geqq 1$ における付着剛性低下率であり， $\varphi_{1}$ は $t=1$ におけるクリープ係数である。

パラメータ $\alpha$ は $t=1$ における相対すべり $S_{t=1}$ の瞬 時すべり $S_{t=0}$ に対する比; 即ち， $\alpha=S_{t=1} / S_{t=0}$ である。 仮定(6に従うと, $\tau_{y}=K_{0} S_{t=0}, \tau_{y}=K_{1} S_{t=1}$ が成立つので, $K_{1}=K_{0} / \alpha$ となる。

パラメータ $\eta$ は瞬時の付着剛性 $K_{0}$ と終局時の付着剛 性 $K_{\infty}$ と比率 $K_{\infty} / K_{0}$ が与えられれば，次式で与えられ る。

$$
\eta=\frac{1}{\varphi_{\infty}-\varphi_{1}}\left\{\frac{1}{\alpha\left(\frac{K_{\infty}}{K_{0}}\right)}-1\right\}
$$

ここでは，文7）より $\alpha=1.2$ を，また文 8) より大

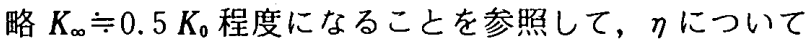
は次式を用いることにする。

$$
\eta=\frac{1}{\varphi_{\infty}-\varphi_{1}}\left(\frac{2}{\alpha}-1\right)=\frac{2}{3\left(\varphi_{\infty}-\varphi_{1}\right)}
$$

$(3 \cdot b)$ 式は今後実験的にさらに検討する必要がある が，一応，既往の文献と比較すると次のようである。

文7）では載荷直後から $t=1$ 日間における付着剛性 の低下率を解析的に約 0.63 とし，その後は一定にみな

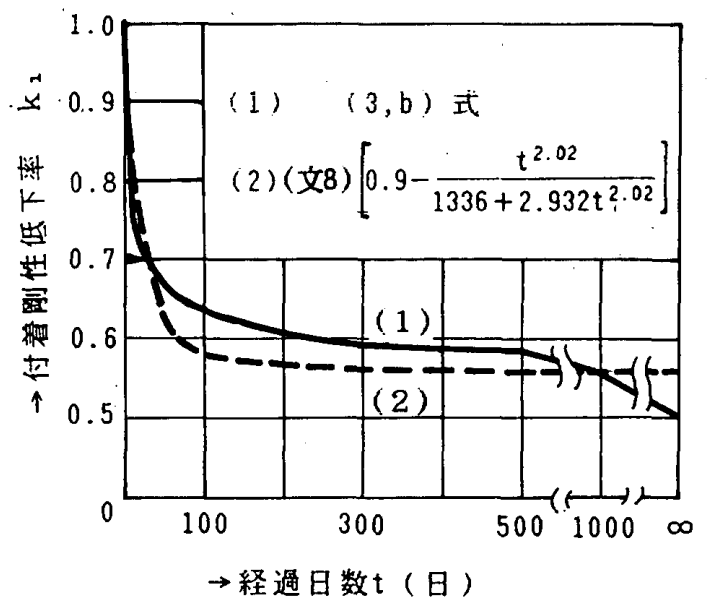

図一3（3.b）式と（文8）の付着㴊性低下率の比較 
すとして扱っているが，これは $(3 \cdot \mathrm{b})$ 式によれば大略 $t=50 \sim 150$ 日間の低下率に相当する。また，文 8）で は剛性低下率についての実験結果を曲線式で求めている が，その式と $(3 \cdot b)$ 式とを比較すると図一 3 のように なる。比較的短期間（大略 $t=0 \sim 50$ 日）の間を除いて は，両者の剛性低下率は実用上大差ないようである。

2-5 弾塑性領域における付着応力ーすべり関係式

時間とともに進行する場合の弾塑性付着応力問題にお いては塑性域が時間とともに変動するとともに，またそ の区域における付着応力の大きさも経時的に変動するこ

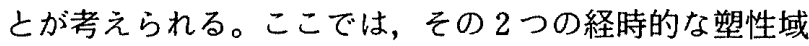
および付着応力の変動を仮定(6)と(7)の下で $(7-1,2)$ 式 のように表示する。

なお，lは 2-4 b-1 節の付着劣化で述べたように有効 定着長であり, $t=0$ で $l=L, t \geqq 1$ では片引き試験体 に対し $l=L-\beta f$, 両引き試験体に対し $l=L-2 \beta f$ で ある。

［1］弾性域（片引き試験体の場合 $a \leqq x \leqq l$, 両引 き試験体の場合 $a \leqq x \leqq l / 2)$ $\tau=K_{t} S \quad\left(S \leqq S_{y}\right)$

[2] 塑性域（片引き・両引き両試験体共 $0 \leqq x \leqq a)$ ○塑性域が経時的に進展する場合

$$
\tau=\tau_{y} \quad\left(S>S_{y}\right)
$$

○塑性域が経時的に進展しない場合

$$
\tau=\tau_{a}^{*}\left(S>S_{y}\right)
$$

ここで, (7-2) 式の $\tau_{a}$ は塑性域と弾性域の境界 $x=$ $a$ における付着応力を表す。また, $a$ の値は仮定(7)によっ て経時的に大きくなっても小さくなることはないとす る。

なお，定着域全域が弾性域にある場合 $(7-1,2)$ 式は 必要としない。

$$
\text { 2-6 コンクリートのクリープと乾燥収縮 }
$$

コンクリートのクリープ昰は有効弾性係数法で, 乾燥 収縮歪 $\epsilon_{s h}$ はクリープ係数 $\varphi_{t}$ に比例するとする。

$$
\begin{aligned}
& E_{t}=\frac{E_{c}}{1+\varphi_{t}} \\
& \epsilon_{s h}=k_{s h} \varphi_{t}
\end{aligned}
$$

ただし， $k_{s h}$ は実験デー夕等から定まる比例定数。

2-7 付着応力問題の基礎式

[1] 弾性域（片引き試験体で $a \leqq x \leqq l$, 両引き試 験体で $a \leqq x \leqq l / 2)$

$$
\begin{aligned}
& \frac{d^{2} S_{e}}{d x^{2}}=\frac{1+n p}{E_{s} A_{s}} \psi K_{t} S_{e} \\
& \frac{d S_{e}}{d x}=\frac{1+n p}{E_{s}} \sigma_{s e}-\frac{n p}{E_{s}} \sigma_{s 0}+\epsilon_{s h}
\end{aligned}
$$

[2] 塑性域 $(0 \leqq x \leqq a)$

$$
\frac{d^{2} S_{\rho}}{d x^{2}}=\frac{1+n p}{E_{s} A_{s}} \psi \tau_{\rho} \quad(=\text { 一定 })
$$

$$
\frac{d S_{\rho}}{d x}=\frac{1+n p}{E_{s}} \sigma_{s \rho}-\frac{n p}{E_{s}} \sigma_{s 0}+\epsilon_{s h} .
$$

ただし， $S_{e}$ と $\sigma_{s e}$ は弾性域の， $S_{\rho}$ と $\sigma_{s p}$ は塑性域の 相対すべり量と鉄筋応力を表す。

また，(11・a) 式中の $\tau_{p}$ は塑性域が経時的に進展する 場合 $\tau_{p}=\tau_{y}$, 進展しない場合 $\tau_{p}=\tau_{a}\left(<\tau_{y}\right)$ である。

\section{2-8 境界条件と連続条件}

\section{[1] 境界条件}

$$
\text { 鉄筋応力に対し }\left.\quad \sigma_{s \rho}\right|_{x=0}=\sigma_{s 0} \text { (両・片) }
$$

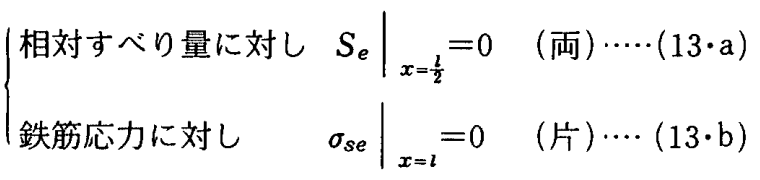

[2] 連続条件：弾塑性域境界 $x=a$ において。

（両），(片）共に共通。

○塑性域が経時的に進展する場合

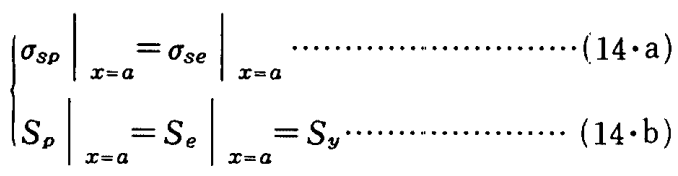

○塑性域が経時的に進展しない場合

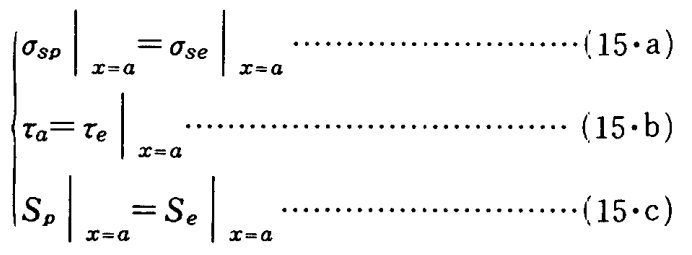

ただし，上式中の（両）は両引き試験体を（片）は 片引き試験体を，(両・片）は両試験体に共通であるこ とを示す。また，定着域全域が弾性である時には（14） 〜(15) 式は必要でない。

2-9 一般解

弾性域および塑性域の一般解は（10）式上（11）式と からそれぞれ次のようになる。

[1] 弾性域

$$
\begin{aligned}
& S_{e}=C_{1} e^{\alpha x}+C_{2} e^{-\alpha x} \ldots \ldots \ldots \ldots \ldots \ldots \ldots \ldots(16, a) \\
& \frac{1+n p}{E_{s}} \sigma_{s e}-\frac{n p}{E_{s}} \sigma_{s 0}=\alpha\left(C_{1} e^{\alpha x}-C_{2} e^{-\alpha x}\right)-\epsilon_{s h}
\end{aligned}
$$

[2] 塑 性 域

$$
\begin{gathered}
S_{\rho}=\frac{1+n p}{2 E_{s} A_{s}} \psi \tau_{\rho} x^{2}+C_{3} x+C_{4} \cdots \cdots \cdots \cdots \cdots(17 \cdot \mathrm{a}) \\
\frac{1+n p}{E_{s}} \sigma_{s \rho}-\frac{n p}{E_{s}} \sigma_{s 0}=\frac{1+n p}{E_{s} A_{s}} \psi \tau_{\rho} x-\epsilon_{s h}+C_{3} \\
\cdots \cdots \cdots \cdots \cdots \cdots \cdots \cdots \cdots \cdots \cdots \cdots \cdots \cdots \cdots \cdots \cdots \cdots \cdots \cdots \cdots \\
\alpha=\sqrt{\frac{1+n p}{E_{s} A_{s}}} \psi K_{\iota}
\end{gathered}
$$

ただし， $C_{1} \sim C_{4}$ は未知積分定数。 


\section{3. 弾塑性付着問題の解}

\section{3-1 解析方法}

解は（16）式之（17）式の関数について境界条件に対 し両引き試験体の場合 $(12)$ 式と $(13 \cdot a)$ 式を, 片引き 試験体の場合 (12) 式と (13・b) 式を用いるのが異な るが，連続条件に対し両引きと片引き試験体の区別なく 塑性域が経時的に進展する場合（14）式を，進展しない 場合（15）式を適用して求める。未知量は積分定数 $C_{1}$ $\sim C$ 、の他に塑性域が経時的に進展する場合 $a$ であり, 進展しない場合 $\tau_{a}$ である。

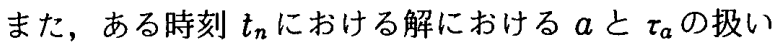

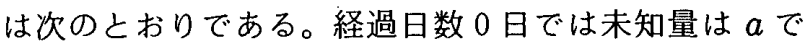
あるが， $t_{n}$ においては最初に $\tau_{a}$ を計算し，もし， $\tau_{a} \geqq$ て である時には塑性域が経時的に進展するとして解き， $\tau_{a}<\tau_{y}$ の時は改めて塑性域が経時的に進展しないとして 解く。この場合 $\tau_{a}$ が未知量となるが, その際， $a$ は $t_{n}$ の前時刻 $t_{n-1}$ において求まった值を既知量として用い る。

\section{3-2 $a, \tau_{a}$ および $C_{1} \sim C_{4}$ の値}

ここでは，弾塑性域に対する $a ， \tau_{a}$ および $C_{1} \sim C_{1}$ の 値を示す。全域が弾性状態にある場合は (16) 式と境界 条件（12）式あるいは（13）式とから簡単に求められる のでここでは省略する。

［1］両引き試験体の場合

$C_{1} \sim C_{4}$ の値は結果として次のように求まる。

$$
\begin{aligned}
& C_{1}=C_{0} e^{-\frac{\alpha l}{2}} \\
& C_{2}=C_{0} e^{\frac{\alpha l}{2}} .
\end{aligned}
$$

ただし，

$$
\begin{aligned}
& C_{0}=\frac{\frac{1+n p}{E_{s} A_{s}} \psi \tau_{p} a+\frac{\sigma_{s 0}}{E_{s}}+\epsilon_{s h}}{2 \alpha \cosh \alpha\left(\frac{l}{2}-a\right)} \\
& C_{3}=\frac{\sigma_{s 0}}{E_{s}}+\epsilon_{s h} \\
& C_{4}=C_{1} e^{\alpha a}+C_{2} e^{-\alpha a}-\frac{1+n p}{2 E_{s} A_{s}} \psi \tau_{p} a^{2} \\
& -\left(\frac{\sigma_{s 0}}{E_{s}}+\epsilon_{s h}\right)
\end{aligned}
$$

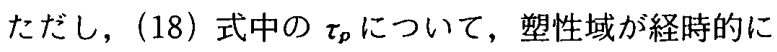
進展する場合 $\tau_{p}=\tau_{y}$, 塑性域が経時的に進展しない場合 (20) 式の $\tau_{a}$ を用いる。

塑性域が経時的に進展する場合の弾塑性境界位置 $a$ は, $\left.S_{e}\right|_{x=a}=S_{y}$ を満足する式として次の (19) 式が導 かれるが，この式を $a$ について解くことによって与え られる。

$$
f(a)=\tanh \alpha\left(\frac{l}{2}-a\right)
$$

$$
\times\left(\frac{1+n p}{A_{s}} \psi \tau_{y} a+\sigma_{s 0}+E_{s} \epsilon_{s h}\right)+\frac{\alpha}{K_{t}} E_{s} \tau_{y}=0
$$

塑性域が経時的に進展しない場合の塑性域における付 着応力 $\tau_{a}$ は $(15 \cdot a)$ 式から次のように求まる。

$$
\tau_{a}=\frac{K_{t}\left(\sigma_{s 0}+E_{s} \epsilon_{s h}\right) \tanh \alpha\left(\frac{l}{2}-a\right)}{E_{s} \alpha+\frac{K_{t}(1+n p)}{A_{s}} \psi a \tanh \alpha\left(\frac{l}{2}-a\right)}
$$

鉄筋変位 $u_{s}$ は $u_{s}=\left(\int \sigma_{s} d x\right) / E_{s}$ であるから, 塑性 域で $u_{s p}$, 弾性域で $u_{s e}$ とする之

$$
\begin{aligned}
u_{s p}= & \frac{1}{E_{s}}\left(\frac{\psi \tau_{p}}{2 A_{s}} x^{2}+\sigma_{s 0} x+C_{5}\right) \\
u_{s e}= & \frac{1}{1+n p}\left\{C_{1} e^{\alpha x}+C_{2} e^{-\infty x}\right. \\
& \left.+\left(\frac{n p}{E_{s}} \sigma_{s 0}-\epsilon_{s h}\right) x+C_{6}\right\}
\end{aligned}
$$

となる。ここで積分定数 $C_{5}$ と $C_{6}$ は連続条件 $\left.u_{s \rho}\right|_{x=a}$ $=\left.u_{s e}\right|_{x=a}$ と $\left.u_{s e}\right|_{x=l / 2}=0$ の 2 つから定めることがで きる。

弾塑性域 $0 \leqq x \leqq l / 2$ における平均付着応力 $\tau_{a v}$ は

$$
\tau_{a v}=\frac{1}{l / 2}\left\{\int_{0}^{a} \tau_{p} d x+\int_{a}^{l / 2} K_{t} S_{e} d x\right)
$$

より次のようになる。

$$
\begin{aligned}
\tau_{a v}= & \frac{2 \tau_{a} a}{l \cosh \alpha\left(\frac{l}{2}-a\right)}+\frac{2 E_{s} A_{s}}{l(1+n p) \psi} \\
& \times\left(\frac{1}{\cosh \alpha\left(\frac{l}{2}-a\right)}-1\right)\left(\frac{\sigma_{s 0}}{E_{s}}+\epsilon_{s h}\right)
\end{aligned}
$$

［2］片引き試験体の場合

$C_{1} \sim C_{4}$ は結果として次のように求まる。

$$
\begin{aligned}
& C_{1}=\frac{1}{C_{0}}\left\{\frac{\tau_{p}}{K_{t}}+\frac{e^{\alpha(l-\alpha)}}{\alpha}\left(\epsilon_{s h}-\frac{n p}{E_{s}} \sigma_{s 0}\right)\right\} \\
& C_{2}=\frac{1}{C_{0}}\left\{\frac{\tau_{p}}{K_{t}}-\frac{e^{\alpha(l-a)}}{\alpha}\left(\epsilon_{s h}-\frac{n p}{E_{s}} \sigma_{s 0}\right)\right\}
\end{aligned}
$$

ただし，

$$
\begin{aligned}
& C_{0}=2 e^{\alpha l} \cosh \alpha(l-a) \\
& C_{3}=\frac{\sigma_{s 0}}{E_{s}}+\epsilon_{s h} \\
& C_{\mathbb{4}}=\frac{\tau_{p}}{K_{t}}-\frac{1+n p}{2 E_{s} A_{s}} \psi \tau_{p} a^{2}-\left(\frac{\sigma_{s 0}}{E_{s}}+\epsilon_{s h}\right) a
\end{aligned}
$$

上式中の $\tau_{\rho}$ の扱いは $(18 \cdot \mathrm{a} \sim \mathrm{e})$ 式の場合のそれと同 じであり， $\tau_{y}$ あるいは $(25)$ 式の $\tau_{a}$ を使い分ける。 塑性域が経時的に進展する場合の弾塑性境界位置 $a$ 
は, $\left.S_{e}\right|_{x=a}=S_{y}$ を満足する式として (24) 式が導かれ るが,この式を $a$ について解くことによって与えられ る。

$$
\begin{aligned}
f(a)= & \frac{E_{s} A_{s} \alpha \tau_{y}}{K_{t}(1+n p)} \tanh \alpha(l-a)+\psi \tau_{y} a \\
& +\frac{A_{s}}{1+n p}\left\{\left(1-\frac{1}{\cosh \alpha(l-a)}\right) E_{s} \epsilon_{s h}\right. \\
& \left.+\left(1+\frac{n p}{\cosh \alpha(l-a)}\right) \sigma_{s 0}\right\}=0 \cdots \cdots(2)
\end{aligned}
$$

また, 塑性域が経時的に進展しない場合の塑性域にお ける付着応力 $\tau_{a}$ は $(15 \cdot a)$ 式より次のように求まる。

$$
\tau_{a}=-\frac{\sigma_{s 0}+E_{s} \epsilon_{s h}+\frac{n p \sigma_{s 0}-E_{s} \epsilon_{s h}}{\cosh \alpha(l-a)}}{\frac{E_{s} \alpha}{K_{t}} \tanh \alpha(l-a)+\frac{(1+n p)}{A_{s}} \psi \tau_{a}}
$$

鉄筋とコンクリートの変位 $u_{s}, u_{c}$ は, 両引き試験体 の場合その基準点 $\left(u_{s}=u_{c}=0\right)$ が試験体の中央になる ので問題は起きないが, 片引き試験体の場合境界条件

(12) 式と（13）式とは変位に関する条件式ではないの で， $u_{c}$ の基準 $\left(u_{c}=0\right)$ の位置をどこにするかによって $u_{c}$ のみならず $u_{s}$ も異なってくる。そのため,これを考 慮しないと, 片引き試験体の鉄筋の抜出しに関する実験 での解析值と実験值との比較を正しく検討できない恐れ がある。そこで, この観点から $u_{s} と u_{c}$ の算定方法を 示す。

コンクリート応力 $\sigma_{c}$ と鉄筋応力 $\sigma_{s}$ との間には次の関 係がある： $\sigma_{c}=-p\left(\sigma_{s}-\sigma_{s 0}\right)$ 。

また， $u_{c}$ は次式で計算できる。

$$
u_{c}=\int\left(-\epsilon_{s h}+\frac{\sigma_{s}}{E_{s}}\right) d x
$$

したがって，塑性域および弾性の $u_{c}$ をそれぞれ $u_{c \rho}$, $u_{c e}$ とすると

$$
\begin{aligned}
u_{c \rho}= & -\frac{p \psi \tau_{p}}{2 E_{t} A_{s}} x^{2}-\epsilon_{s h} x+D_{1} \cdots \cdots \cdots \\
u_{c e}= & \frac{1}{1+n p}\left\{-n p\left(C_{1} e^{\alpha x}+C_{2} e^{-\infty x}\right)\right. \\
& \left.+\left(\frac{p \sigma_{s 0}}{E_{t}}-\epsilon_{s h}\right) x\right\}+D_{2} \cdots \cdots \cdots \cdots
\end{aligned}
$$

ただし， $D_{1}$ と $D_{2}$ は積分定数。

ここで, 試験体中の任意位置 $x=g$ で $u_{c}=0$ なる条件 を与えればよいが， $g$ が塑性域 $(0 \leqq x \leqq a)$ にある場合 と弾性域 $(a \leqq x \leqq l)$ にある場合とでは $D_{1}$ と $D_{2}$ の值 が異なる。

$$
\left\{\begin{array}{l}
0 \leqq g \leqq\left. a \cdots u_{c \rho}\right|_{x=g}=0,\left.\quad u_{c p}\right|_{x=a}=\left.u_{c e}\right|_{x=a} \\
a \leqq g \leqq\left. l \cdots u_{c \rho}\right|_{x=g}=0,\left.\quad u_{c \rho}\right|_{x=a}=\left.u_{c e}\right|_{x=a}
\end{array}\right.
$$

のいずれかを解くことによって $D_{1}$ と $D_{2}$ が定まる。

鉄筋変位 $u_{s}$ は相対すべり量 $S$ と $u_{c}$ との関係から次
式で求まる。

$$
u_{s}=S+u_{c}
$$

平均付着応力 $\tau_{a v}$ は

$$
\begin{aligned}
\tau_{a v} & =\frac{1}{l}\left\{\int_{0}^{a} \tau_{p} d x+\int_{a}^{l} K_{t} S d x\right\} \\
& =-\frac{A_{s} \sigma_{s 0}}{\psi l} \ldots \ldots \ldots \ldots \ldots \ldots \ldots \ldots \ldots \ldots \ldots
\end{aligned}
$$

となる。上式から, bi-linear 型の付着応力ーすべり関係 を用いる場合の片引き試験体での $\tau_{a v}$ は, 弾塑性および 経時変化に関係なく, 常に一定で, 加力端鉄筋応力と鉄 筋寸法 (断面積, 周長, 定着長) で決まることが分る。

3-3 加力端における鉄筋の抜出し量と鉄筋の伸び

3-1 と 3-2 で有効定着域での相対すべり，付着応力お よび鉄筋変位等が求まると, 加力端位置におりる鉄筋の 抜出し量 $S_{w}$ と両引き試験体における鉄筋の伸び $\delta$ は仮 定(9)から次式で計算できる。ただし， $\delta$ は試験体中に埋 込まれた（定着長 $L)$ 鉄筋の全長にわたる変形量のこ とをいう。

$$
\begin{aligned}
& S_{w}=S_{0}+\frac{\sigma_{s 0}(\beta f)}{E_{s}} \quad(\text { 片・両試験体共通 }) \\
& \delta=2\left\{u_{s 0}+\frac{\sigma_{s 0}(\beta f)}{E_{s}}\right\} \quad \text { (両引き試験体) }
\end{aligned}
$$

ただし， $S_{0}, u_{s 0}$ はそれぞれ有効定着域の $x=0$ にお ける相対すべり, 鉄筋変位を表し, 上式の第 2 項は付着 応力が消失する区間（加力端から $\beta f$ 迄の区間）におけ る鉄筋の伸び量である。

3-4 乾燥収縮の影響

コンクリートの乾燥収縮歪 $\epsilon_{s h}$ のみの影響による付着 応力問題では一般に弾性状態を対象としてよいので, 3-2 中の [1] あるいは［2］のいずれかの定式化にお いて $\sigma_{s 0}=0, a=0$ として求めることができる。

\section{4. 既往の実験結果との比較}

ここでは, 鈴木・大野らの両引き試験体”および小柳 らの片引き・両引き試験体の実験結果 ${ }^{5)}$ に対して前節の 定式化による解析を適用し, この解析方法の妥当性を検 討する。

\section{4-A 鈴木・大野らの実験 ${ }^{7}$}

\section{A-1 実験条件および試験体}

実験は温度 $20 \pm 1^{\circ} \mathrm{C}$, 相対湿度 $60 \pm 5 \%$ の恒温 - 恒 湿室で行われており, また試験体の寸法と材料の力学的 性質を表一1に示す。ただし， $\tau_{y}$ と： $K_{0}$ は同文献中に示 されている

$$
\left\{\begin{array}{l}
\tau_{\max }=15.2(C / R)+7.5 \\
\frac{\tau}{\tau_{\max }}=1000\left(\frac{S}{L / 2}\right) \quad\left(S \leqq S_{y}\right)
\end{array}\right.
$$

から求めた。 
表一1 試験体の実験条件と寸法（鈴木・大野等の実験）

\begin{tabular}{|c|c|c|c|c|c|}
\hline \multicolumn{2}{|c|}{$\begin{array}{l}\text { 両引き試騟体と片引 } \\
\text { き試験体との区别 }\end{array}$} & 両 & 雨 & 両 & 両 \\
\hline \multicolumn{2}{|r|}{ 試験体名 } & N10-1 & $\mathrm{N} 10-2$ & S10-1 & S10-2 \\
\hline & $L(\mathrm{cti})$ & \multicolumn{4}{|c|}{21} \\
\hline \multicolumn{2}{|c|}{$\sigma 50\left(\mathrm{kgf} / \mathrm{cm}^{2}\right)$} & \multirow{2}{*}{\multicolumn{4}{|c|}{2000}} \\
\hline \multicolumn{2}{|r|}{$\tau y\left(\mathrm{kgf} / \mathrm{cm}^{2}\right)$} & & & & \\
\hline \multicolumn{2}{|r|}{$\mathrm{Ko}\left(\mathrm{kgf} / \mathrm{cm}^{3}\right)$} & \multicolumn{4}{|c|}{3810} \\
\hline \multicolumn{2}{|c|}{$\alpha$} & \multicolumn{4}{|c|}{1.2} \\
\hline \multirow{2}{*}{\multicolumn{2}{|c|}{$\frac{\beta}{\alpha 4}$}} & \multicolumn{4}{|c|}{2} \\
\hline & & \multicolumn{4}{|c|}{ D19-SD30 } \\
\hline \multirow[t]{4}{*}{ 筋 } & $f(\mathrm{~cm})$ & \multicolumn{4}{|c|}{1.20} \\
\hline & As $\left(\mathrm{Cm}^{2}\right)$ & \multicolumn{4}{|c|}{2.87} \\
\hline & $\psi(\mathrm{Cm})$ & \multicolumn{4}{|c|}{6.0} \\
\hline & Es $\left(\mathrm{kgf} / \mathrm{cm}^{2}\right)$ & \multicolumn{4}{|c|}{$2.1 \times 10^{6}$} \\
\hline$\exists$ & $E c\left(\mathrm{kgf} / \mathrm{cm}^{2}\right)$ & \multicolumn{4}{|c|}{$2.3 \times 10^{3}$} \\
\hline y & $A c\left(\mathrm{Cm}^{2}\right)$ & \multicolumn{4}{|c|}{100} \\
\hline$\eta$ & \multirow[t]{2}{*}{$\overline{\phi t}$} & \multicolumn{4}{|c|}{$t^{0.5}$} \\
\hline リ & & \multicolumn{4}{|c|}{$0.378 t^{0.5}+3.527$} \\
\hline $\begin{array}{l}1 \\
1\end{array}$ & $\varepsilon \operatorname{sh}\left(\times 10^{-4}\right)$ & $\overline{0.123 t}$ & +2.08 & 0.0976 & +34.7 \\
\hline
\end{tabular}

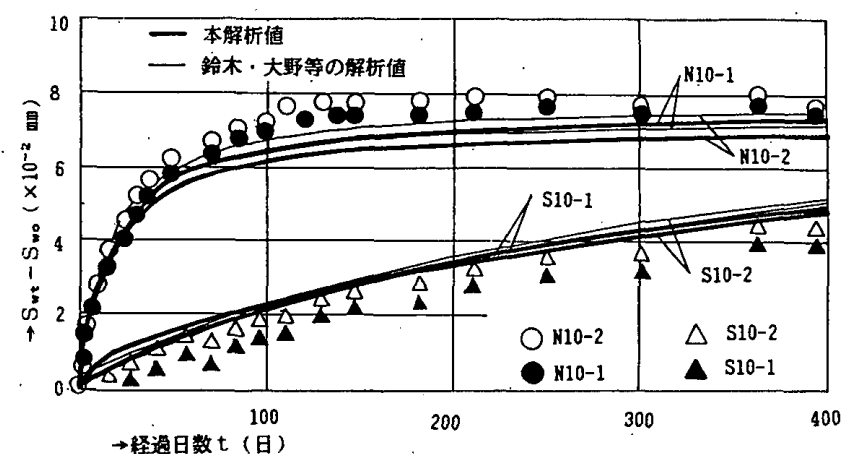

図一4鉄筋の抜出し増加量に関する実験結果と本解析値との比 較（両引き試験体，鈴木・大野等の実験）

\section{A-2, 実験結果と解析結果の比較}

図一4に各試験体の鉄筋の抜出しの増加量（載荷直後 の抜出し量を 0 とする) の経時変化を示す。図中の太い 実線は本解析値を示す。また，細線は鈴木・大野らの解 析値である。

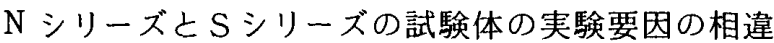
は加カレベルとコンクリートの乾燥収縮昰の 2 点であ り，鉄筋の抜出しの增加量は加力レベルではなく，主に コンクリートの乾燥収縮に影響を受けることが実験的に 示されているが，このことは本解析からも肯首できる。

なお，鉄筋の抜出しの増加量について本解析結果は鈴 木・大野らの解析結果に近似した。

鉄筋の伸びについては実験結果で触れられていないた め分からないが，本解析では載荷直後の値に対し経過日 数約 400 日で大概 0 5\%の微增加しか認められず，経 時的に大略載荷直後の値を保つという結果を得た。

表一 2 に，経過日数約 400 日における鉄筋の抜出し增 加量と，両引き試験体中央位置の鉄筋歪値についての解 析値と実験值との比較を示す。S 10-1 を除く他の試験
表一2 鈴木・大野等の実験結果と本解析結果との比較 $(t \fallingdotseq$ 400 日)

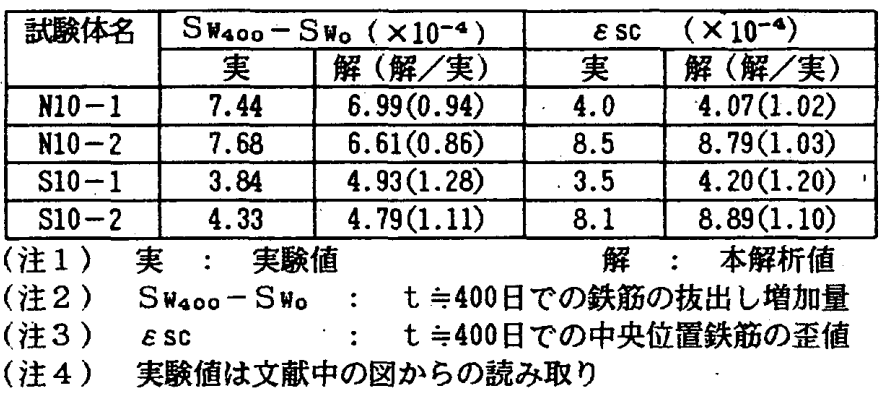

体の解析値は実験値の約 $0.85 \sim 1.15$ 倍の範囲内に収 まっている。

なお，本解析での付着応力ーすべり関係は全試験体と も弾性範囲であった。

\section{4-B 小柳らの実験 ${ }^{5}$}

小柳らが報告した両引き試験体と片引き試験体の実験 結果について前節の定式化による本解析を適用し；その 妥当性を検討する。この実験の目的は，長期にわたる持 続荷重下でスラブ端部におけるスタブ部分を両引き試験 体と片引き試験体にモデル化して，主に，前者に対して 鉄筋の伸びを，後者に対して引張鉄筋の経時的な抜出し 等を考察したもので，解析的な検討を行っていない。加 力端鉄筋応力レベルは長期設計時応力およびその $1 / 2$ の 大きさを扱っている。

実験は恒温・恒湿室と地下室の両方で行うているが, 実験結果は主に加力端鉄筋応力レベルで分けてまとめて ある。

\section{B-1 実験条件および試験体}

試験体の寸法と材料の力学的性質を表一 3 に示す。 表一3について，以下に若干の説明を加える。

(1) コンクリートの解析用断面寸法

全試験体共コンクリート断面は図一 5 に示すように 15 $\times 15 \mathrm{~cm}$ の大きさであるが，鉄筋位置は中央ではなく偏 心している。ここでは，六車・森田博士の解析方法"1に 従い，引張鉄筋とコンクリートの図心とが一致するコン クリート部分が引張力分担に対して有効であるとし，6 $\mathrm{D} \times 6 \mathrm{D}$ の部分 ( $\mathrm{D}$ ：異形鉄筋の直径, 図一 5 中ハッチ 部分）をコンクリートの解析用断面とした注2)。

(2) 瞬時弾性付着剛性 $K_{0}$ と付着強度 $\tau_{y}$

小柳等は付着応力ーすべり関係を求める基本実験を 行っていないので直接には瞬時弾性付着剛性 $K_{0}$ が不明 であるが，表一3に示した長期載荷実験用試験体之は別 に作成した片引き試験体（ただし．試験体寸法と使用材 料は表一 3 中の片引き試験体と同一)によって鉄筋の抜 出しに関する短期載荷実験を実施しているので， $K_{0}$ は この実験結果を利用して定めた。すなわち，この実験結 果と， $K_{0}$ を数值的に種々変化させて求めた解析結果と を比較すると図一6のようになる。 $K_{0}$ は，最大荷重 
表一3 試験体の実験条件と寸法

\begin{tabular}{|c|c|c|c|c|c|c|c|c|c|}
\hline & 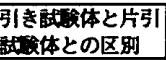 & 西 & 再 & 画 & 宙 & 片 & 片 & 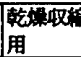 & 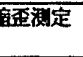 \\
\hline & 体名 & \begin{tabular}{|l|} 
IA, IIA \\
VA, VIA
\end{tabular} & $\begin{array}{l}\text { I B, IIB } \\
\text { VB, , YB }\end{array}$ & IIIA, VIA & IIIB, VI & \begin{tabular}{|l} 
I C, VC \\
IIC, VC
\end{tabular} & IIC, VIC & IVA, VIIA & $\begin{array}{l}\text { INB, NCC } \\
\text { ViB, VEC }\end{array}$ \\
\hline & L (c口) & 40 & 20 & 40 & 20 & & 20 & 40 & 20 \\
\hline & $\overline{\sigma s o}\left(\mathrm{kgf} / \mathrm{cm}^{2}\right)$ & 2000 & (2075) & 1000 & (1091) & $\begin{array}{c}2000 \\
(2075)\end{array}$ & $\begin{array}{c}1000 \\
\text { (1091) }\end{array}$ & & 0 \\
\hline & $\tau y\left(\mathrm{kgf} / \mathrm{cm}^{2}\right)$ & & & & & & & & \\
\hline & $\mathrm{Ko}\left(\mathrm{kgf} / \mathrm{cm}^{3}\right)$ & & & & & 50 & & & \\
\hline & & & & & & 2 & & & \\
\hline & $\bar{\beta}$ & & 2 &. & 1 & 2 & 1 & & 0 \\
\hline & 铁觔往と材悬 & & & & & SD30 & & & \\
\hline & $f(\mathrm{col})$ & & & & & 67 & & & \\
\hline & As $\left(c^{2}\right)$ & & & & & 71 & & & \\
\hline & $\psi(\mathrm{ct})$ & & & & & .0 & & & \\
\hline & Es $\left(\mathrm{kgf} / \mathrm{cm}^{2}\right)$ & & & & & $\times 10^{6}$ & & & \\
\hline$=$ & Ec $\left(\mathrm{kgf} / \mathrm{cm}^{2}\right)$ & & & & & $\times 10^{5}$ & & & \\
\hline & $\operatorname{Ac}\left(c n^{2}\right)$ & & & & & 6 & & & \\
\hline & $\phi \mathrm{t}$ & & & & $\frac{.5}{10.5}$ & $\frac{5 t}{0.25 t}$ & & & \\
\hline & $\varepsilon \operatorname{sh}\left(\times 10^{-2}\right)$ & & & & 1.67 & & & & \\
\hline
\end{tabular}

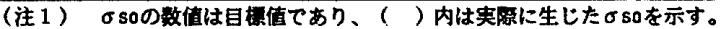

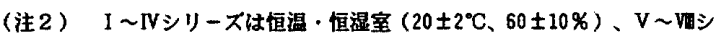
リースは地下室で央騟。

（約 $2.2 \mathrm{tf）の} 1 / 2$ の大きさの荷重における鉄筋の抜出 し量についての解析値が実験値によく近似するときの次 の值を採用した ${ }^{\text {注3)。 }}$

$$
K_{0}=3750 \mathrm{kgf} / \mathrm{cm}^{3}
$$

付着強度 $\tau_{y}$ は, 上述の $K_{0}$ の値を用いて $\tau_{y}$ の值を種々 変化させて解析を行い，この結果と実験結果とを図一7 のように比較して，次の值とした。

$$
\tau_{y}=35 \mathrm{kgf} / \mathrm{cm}^{2}
$$

(3) コンクリートのクリープ係数 $\phi_{t}$ と乾燥収縮歪 $\epsilon_{s h}$ コンクリートのクリープ係数 $\phi_{t}$ はクリープ試験が行 われていないので不明であるが，ここでは，便宜上，恒 温・恒湿室と地下室の区別をしないで標準的な值として 終局クリープ係数 $\phi_{\infty}=3$ を採用し，次式とした ${ }^{12)}$ 。

$$
\phi_{t}=\frac{0.75 t}{10.5+0.25 t} \quad\left(\phi_{\infty}=3\right)
$$

コンクリートの乾燥収縮歪 $\epsilon_{s h}$ は材料奏験結果から終 局時の乾燥収縮歪 $\epsilon_{\text {sho }}$ として $\epsilon_{\text {sho }}=5 \times 10^{-4}$ を採用し, また $\epsilon_{s h}$ は $\phi_{t}$ に比例するとして, 表一 3 中に示す式とし た。

B-2 両引き試験体の解析結果と実験結果との比較 両引き試験体では鉄筋の伸び変化について経時測定を 行っている。この測定は，図一8に示すように，両端か ら $1 \mathrm{~cm}$ 離饥た位置に狭まれる区間 $(L+2) \mathrm{cm}$ で行って いる。

個々の試験体の測定結果は図一9および図一10に示さ れるようにかなりのばらつきがあり，そのため，小柳等 は実験結果を主として加力端鉄筋応カレベルと定着長と で区別し恒温・恒湿室と地下室とでの測定値を平均して 考察している。この実験結果ではコンクリートの乾燥収 縮の影響を補正していない。したがって解析も同様に 行った。

解析に用いた加力端鉄筋応力は表一 3 中の各加力レベ

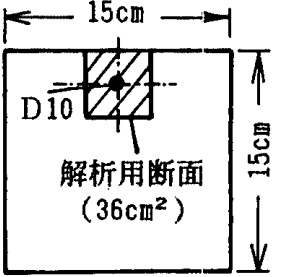

図一5＼cjkstart試験体断面（両引き・片引き試験体共共通）

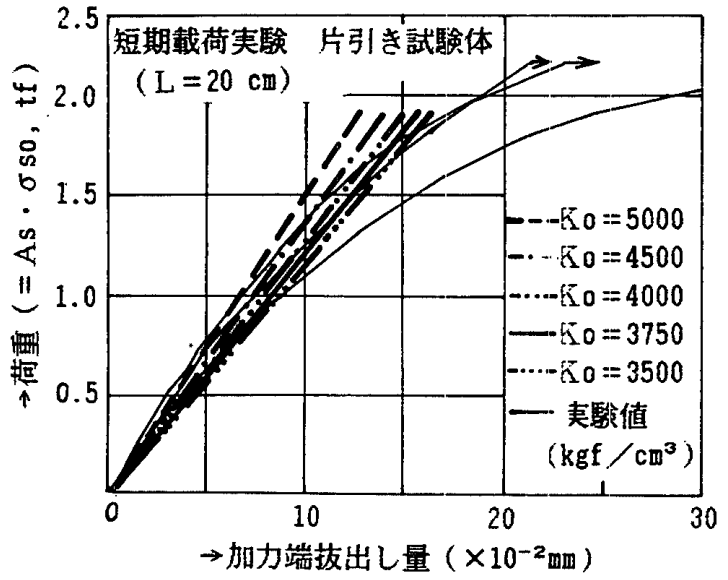

図一6 弾性時付着剛性 $K_{0}\left(\mathrm{kgf} / \mathrm{crn}^{3}\right)$

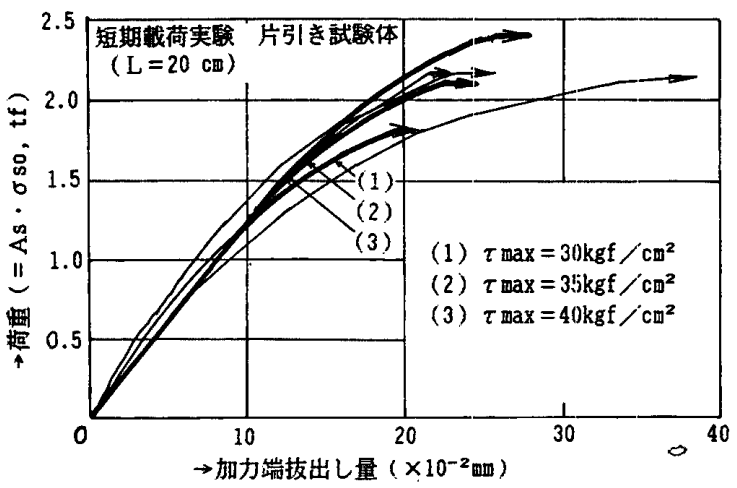

図一7 解析上の付着強度 $\tau \max \left(\mathrm{kgf} / \mathrm{cm}^{2}\right)$ 推定

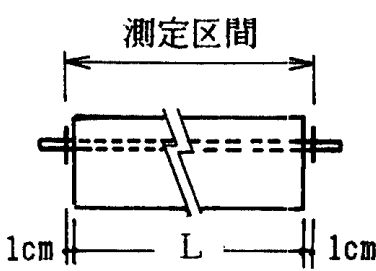

図一8＼cjkstart両引き試験体鉄筋の伸び測定間位置

ル毎の平均值とした。表一4 中の(1)のグループの試験体 に対しては弾塑性解析となったが, 経時的な塑性域の進 展が起こらなかった。すなわち，塑性域で付着応力が経 時的に低下する結果となった。他の 3 つのグループの武 験体の解析は弾性解析であった。

鉄筋の伸び変化は鉄筋の抜出しと:は違うが，解析結果 と実験結果とを比較した。表一4に主な経過曰数での, 図一 9 と図一 10 に経時変化での解析值と実験値との比較 
を示す。

両引き試験体中の鉄筋と同一寸法の鉄筋（これを裸鉄 筋と表現する）の瞬時の伸び試験を行っており，表一4 には，この伸び量も合わせて示してある。

表一4 中で $t=336$ 日の場合(2)と(4)の試験体の実験值 は裸鉄筋の伸び実験值を上回っており，理論的に起こり 得ないことなので, 解析値と実験值との比較においては

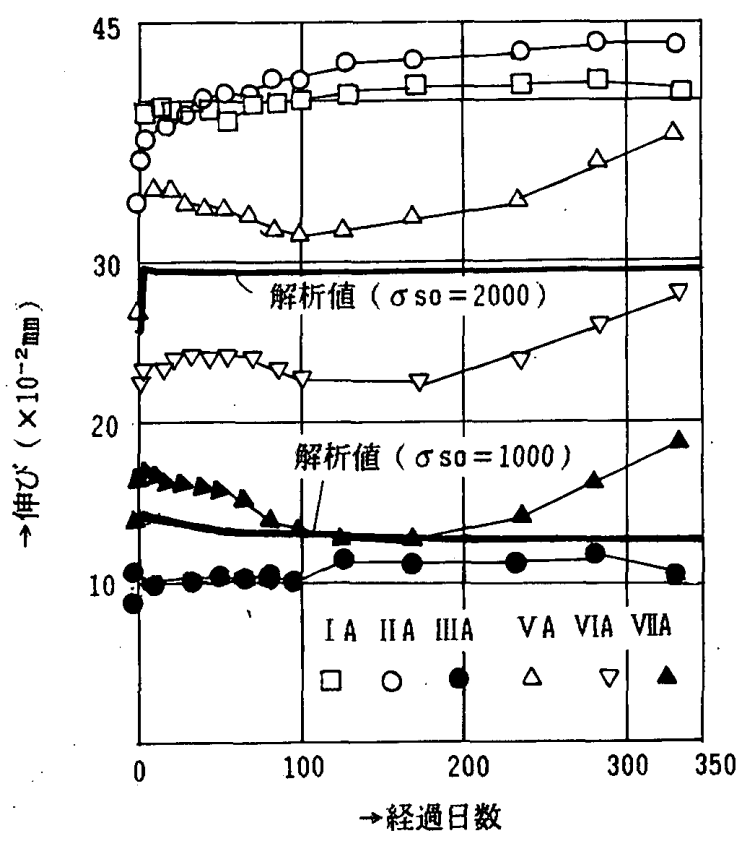

図一9 鉄筋の伸び量（両引き試験体， $L=40 \mathrm{~cm}$ )

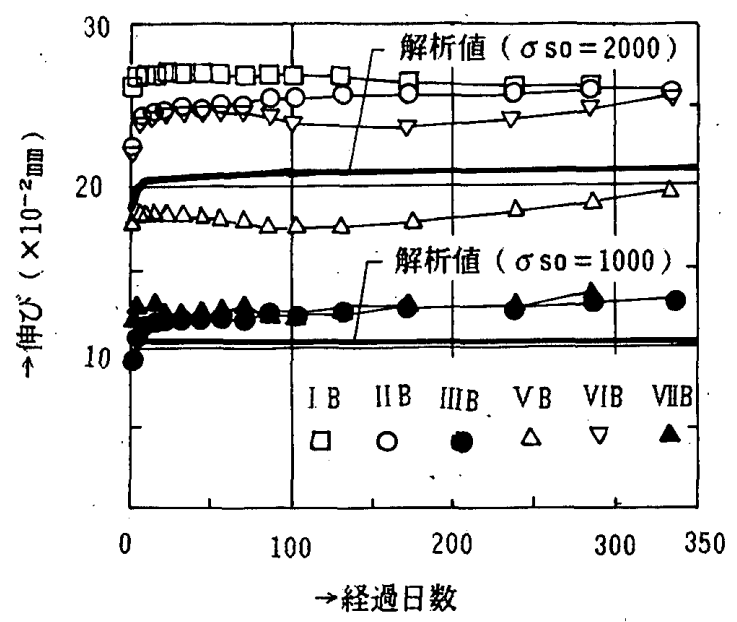

図一10 鉄筋の伸び量（两引き試験体， $L=20 \mathrm{~cm}$ )

表一4 両引き試験体の鉄筋の伸びの解析結果

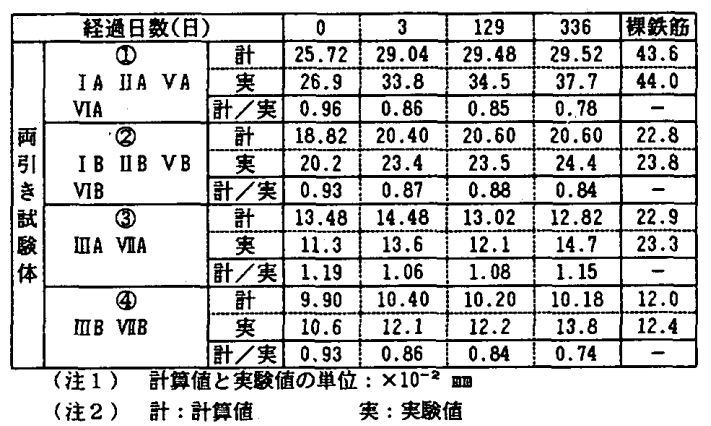

これを無視する。

表一4 から次のことがいえる。

解析値は実験值の約 $0.8 \sim 1.2$ 倍の範囲に収まり, 比 較的良く近似する。ただし，すべての試験体について $t$ $\geqq 3$ 日の場合で（計算值/実験值）が載荷直後 $(t=0)$ の値より約 1 割程度低くなった。これは, 載荷直後 $(t$. =0）から $t=3$ 日間の付着劣化による鉄筋の伸び増加 量について解析值 (約 $0.5 \sim 3.3 \times 10^{-2} \mathrm{~mm}$ ) が実験值 $(1.5$

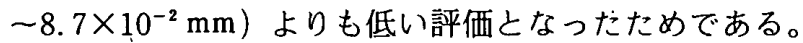

$t=3$ (日) 以後の経時的な鉄筋の伸びについて, 解 析では略々一定值を保つ解となるが, これは, 経過日数 に関係なく大きく変動しないという実験結果を裏付けて いる。

なお，小柳らはこの両引き試験体に対し鉄筋の抜出し に関する測定を行っていないので，これに対しては解析 值と比較することができない。そこで参考のためにこの 試験体に対する鉄筋の抜出しの解析結果について述べて おくと, 解析值は鈴木 - 大野の両引き試験体に対する比 較（4-A）で述べたのと同様に経時的に大きく増大する 結果となった。

図一 9 と図一 10 に鉄筋の伸びについて個々の試験体の 実験值之解析值の経時変化の比較を示す。

両図において， $\sigma_{s 0}=2 \mathrm{tf} / \mathrm{cm}^{2}$ の加力レベルでの本解析 值は恒温・恒湿室の場合よりも地下室での $2 つ$ つ実験結 果の平均的伸び性状に近くなっている。

図一11 に試験体 IA, IB の中央位置 $(x=L / 2)$ にお ける鉄筋丕の解析結果と実験結果との比較を示す。比較 的良く近似している。

B-3 片引き試験体の解析結果と実験結果との比較

図一12に示すように，片引き試験体の鉄筋の抜出し に関する測定方法として，コンクリート側面から 1.5 $\mathrm{cm}$ 内側の位置から鉄筋露出部分の $1 \mathrm{~cm}$ 区間合計 2.5 $\mathrm{cm}$ の区間における変位差を経時的に測定するという方

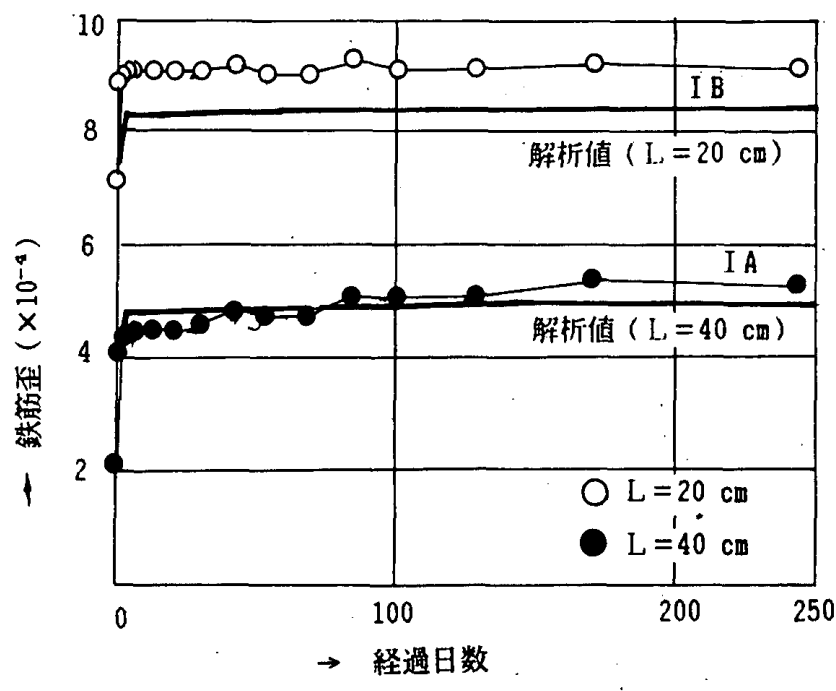

図一11両引き試験体中央位置の鉄筋霆 $\left(\sigma_{s 0}=2000 \mathrm{kgf} / \mathrm{cm}^{2}\right)$ 


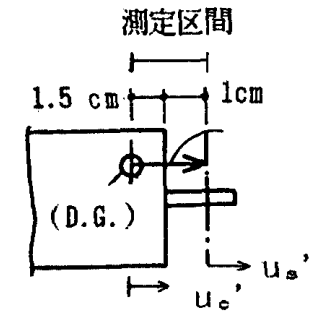

測定値 $=u_{s}^{\prime}-u_{c}{ }^{\prime}$

図一12 片引き試験体変位測定位置

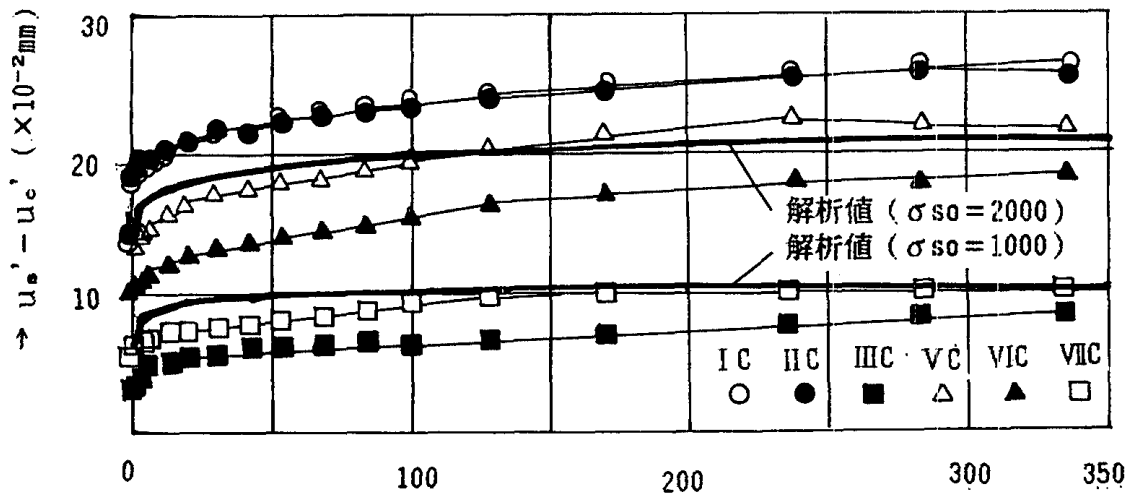

$\rightarrow$ 経過日数

図一13 片引き試験体の加力端の変位 $(L=20 \mathrm{~cm})$
表一5 片引き試験体の変位 $\left(u_{s}^{\prime}-u_{c}^{\prime}\right)$ の解析結果と実験結果 の比較

\begin{tabular}{|c|c|c|c|c|c|c|c|}
\hline \multicolumn{3}{|c|}{ 释题日數(日) } & 0 & 1 & 7 & 101 & 336 \\
\hline \multirow{6}{*}{ 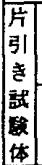 } & \multirow[t]{3}{*}{ IIIC VIC } & 碚 & 6.78 & 7.96 & 8.28 & 9.64 & 10.20 \\
\hline & & 実 & 4.3 & 5.3 & 5.7 & 7.8 & 8.9 \\
\hline & & 辟/实 & 1.58 & 1.50 & 1.46 & 1.24 & 1.15 \\
\hline & \multirow{3}{*}{$\begin{array}{ll}\text { IC } & \text { VC } \\
\text { II C } & \text { VIC }\end{array}$} & 䤃 & 13.30 & 16.34 & 16.99 & 19.89 & 20.93 \\
\hline & & 実 & 11.2 & 14.9 & 16.2 & 20.4 & 23.2 \\
\hline & & 計/実 & 1.19 & 1.10 & 1.09 & 0.98 & 0.90 \\
\hline
\end{tabular}

法を用いている。この場合, 测定値は次式で表される。 測定值 $=u_{s}^{\prime}-u_{c}^{\prime} \quad$ （図-12）

ただし， $u_{s}^{\prime}$ はコンクリート側面から $1 \mathrm{~cm}$ 離れた位置 の鉄筋変位, $u_{c}^{\prime}$ はダイヤルゲージ (D.G) 取付け位置 のコンクリート変位。

解析的には表一3中の片引き試験体に対し（ $u_{s}^{\prime}-u_{c}^{\prime} ）$ の計算値は鉄筋抜出し計算值 $S_{w}$ の約 95 98\% 程度で ほとんど差はなかった。

表一5に主な経過日数における $\left(u_{s}^{\prime}-u_{c}^{\prime}\right)$ の解析値と 実験値との比較を, 図一13に各片引き試験体の経時変 化についての比較を示す。

解析に用いた加力端鉄筋応力値は表一3中の（）内 に示した値としている。また, 実験結果には乾燥収縮の 影響を除いているので, 解析結果も同様にしてある。加 力端鉄筋応力 $\sigma_{s 0}$ が $\sigma_{s 0}=1 \mathrm{tf} / \mathrm{cm}^{2} レ$ レルの試験体に対し ては弾性解析, $\sigma_{s 0}=2 \mathrm{tf} / \mathrm{cm}^{2} レ$ レ゙ルものに対しては弾 塑性解析となった。また, 後者については, 両引き試験 体の場合（B-2参照）と同様に，塑性域での付着応力 が経時的に低下する結果となった。

表一 5 について， $t=336$ 日での解析值は実験值の約 $0.9 \sim 1.2$ 倍の範帇内に収まったが, $\sigma_{s 0}=1 \mathrm{tf} / \mathrm{cm}^{2}$ のも の (IIIC, VIIC) に対し $t=0 \sim 7$ 日の間で解析值は実験 值の約 1.5 倍以上の結果となった。これは表一5で明ら 加のうに，瞬時 $(t=0)$ の解析值が実験值の約 1.6 倍となったためである。

$t=0$ - 1 日間の付着の劣化による増加量について計算 值は $1.12 \sim 3.04 \times 10^{-2} \mathrm{~mm}$, 実験值は $1 \sim 3.7 \times 10^{-2} \mathrm{~mm}$

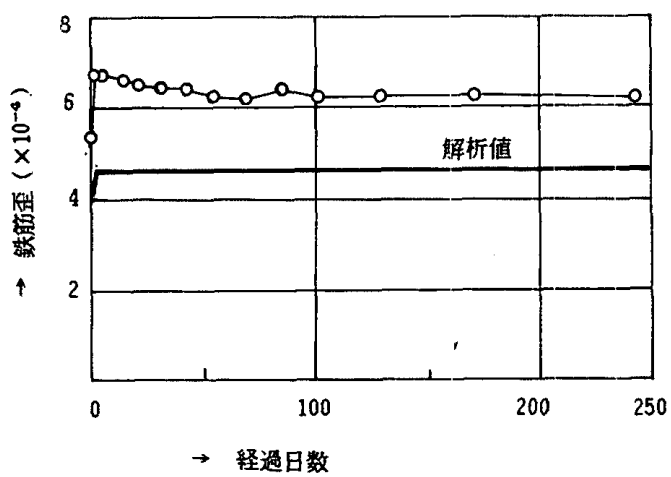

図一14 片引き試験体中央位置の鉄筋昰 $\left(\sigma_{s 0}=2000 \mathrm{kgf} / \mathrm{cm}^{2}\right)$

であり，両引き試験体の場合よりも，計算値は実験値に より良く近似した。

図一13 から分かるように，雨引き試験体の場合と同 様に, 片引き試験体の実験値を大きくばらついているが, 図一 9 と図一 10 の解析結果と実験結果との比較でも述へ たように，本解析値は恒温・恒湿室よりも地下窒での㬰 験結果に長期的によく対応するようである。

図一14に片引き武験体中央位置 $(L / 2)$ の教筋の経 時歪の比較を示す。ただし，この実験結果之解析結果は 共に乾燥収縮の影響を含んでいる。解析値は実験值の約 $75 \%$ 程度である。経過日数 1 日以後の鉄筋歪は解析的 にほぼ一定であるが，これは実験值の定性的傾向を裏付 けている。

\section{B-4 乾燥収縮による影響}

加力を何ら行わない，コンクリートの乾燥収㴼の影響 について両引き試験体の鉄筋の経時的伸び変化（測定区 間は図-8参照) を図一15に，片引き試験体の $\left(u_{s}^{\prime}-u_{c}^{\prime}\right)$ の経時変化を図一16に示す。

両引き試験体の場合, 経過日数 $t=100$ 日前後から約 300 日程度の間で地下室における実験值が解析值の約 1. 5〜3 倍程度大きくなっているが，解析值と実験值は 全体的な傾向として比較的近似しているといえる。片引 き試験体についても同様のことがいえる。 


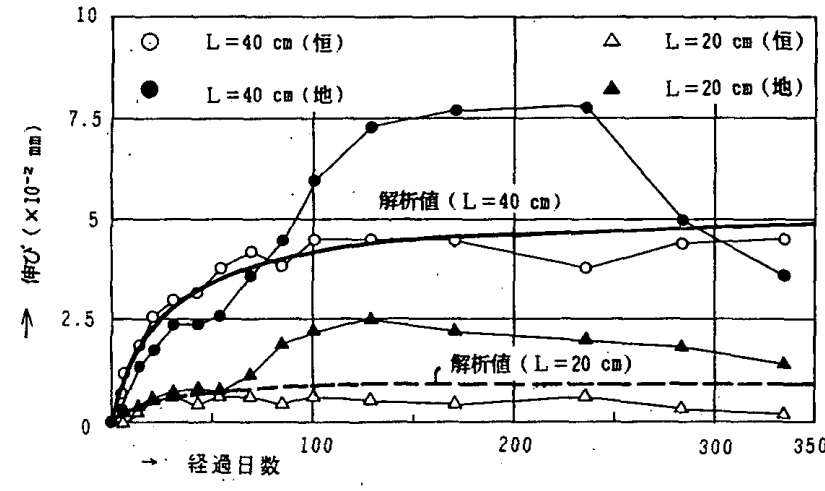

図一15乾燥収縮による鉄筋の伸び量（両引き試験体）

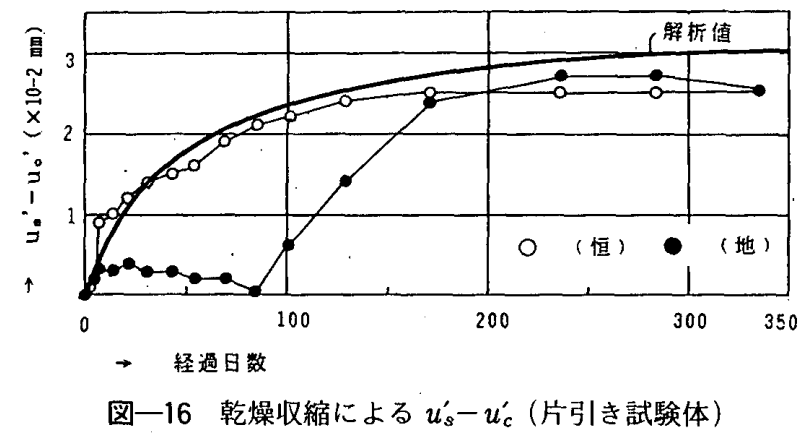

\section{5. 鉄筋の抜出し量算定式と定着長の解析的検討}

\section{5-1 鉄筋の抜出し量算定式}

長期持続荷重下における付着応力ーすべり問題につい て，2-3および2-4に示したような仮定を設けて，3. で図った定式化の妥当性を 4 .で既往の実験結果と比較 することにより検討した。，その結果, 載荷直後から経過 日数 3 日間における鉄筋の伸び増加量に対して過少な評 価がみられた(表一4)ものの, 経時的な鉄筋の抜出し(図 一, 図一13および図一16）の全体的な傾向は実験結果 に比較的良く近似した。

特に, 長期設計持続荷重下においては, 載荷直後より も長期持続載荷（約 1 3 年以後）時での力学的性状を 明らかにすることに重点が置かれるが，この意味で，実 験測定終了時（経過日数約 400 日あるいは 336 日）につ いて表一2 中の各両引き試験体と表一 5 中の片引き試験 体に対する鉄筋の抜出しに対する解析值は，1つの試験 体（S10-1 試験体）を除して, 実験值の約 0.8〜1.2 倍 の範囲内に収まり比較的良好な結果を得た。

鉄筋の抜出し量 $S_{w}$ の算定は, 弾塑性解析では付着応 カーすべり関係に bi-linear 型の比較的簡単なモデルを用 いた場合でも本解析のように数値解析に頼らざるを得な いが, 弾性解析ならばやや繁雑な式になるものの, 次式 で算定できる。

$$
S_{w}=\frac{\sigma_{s 0}(\beta f)}{E_{s}}+S_{0}
$$

ただし， $S_{\mathbf{0}}$ は両引き試験体の場合 $(32 \cdot \mathrm{a})$ 式で，片 引を試験体の場合 $(32 \cdot b)$ 式となる。

$$
\begin{aligned}
S_{0}= & \frac{\cosh \alpha l-1}{\alpha \sinh \alpha l}\left(\frac{\sigma_{s 0}}{E_{s}}+\epsilon_{s h}\right) \ldots \ldots \ldots \ldots \\
S_{0}= & \frac{1}{\alpha \sinh \alpha l}\left\{\frac{\sigma_{s 0}}{E_{s}}(n p+\cosh \alpha l)\right. \\
& \left.-\epsilon_{s h}(1-\cosh \alpha l)\right\} \ldots \ldots \ldots \ldots \ldots \ldots \\
\text { たたしし, } & \begin{cases}l=L & (t=0) \\
l=L-\beta f & (t \geqq 1)\end{cases}
\end{aligned}
$$

$(32 \cdot a, b)$ 式は弾性解析式であるので， $(10 \cdot a, b)$ 式 に対し, 境界条件 (12) 式亡 (13・a) 式で解けば $(32 \cdot a)$ 式を，境界条件 (12) 式と $(13 \cdot b)$ 式で解けば $(32 \cdot b)$ 式を求めることができる。

（31）式が適用できる引張鉄筋応力レベルの範团を調 べるために（31）式と弾塑性解析の結果とを比較した。

解析モデルの材料定数や断面寸法は表一3に示すもの と同じであるが，定着長 $L$ については両引き試験体の 場合 $L=30$ および $50 \mathrm{~cm}$, 片引き試験体の場合 $\mathrm{RC}$ 構 造計算規準12)に示された $L=35 d=35 \mathrm{~cm}$ とした。また， 加力端鉄筋応力 $\sigma_{s 0}$ は $2.0 \sim 2.6 \mathrm{tf} / \mathrm{cm}^{2}$ とした。この加 カレベルは両引き試験体で $\sigma_{s 0}=2.0 \mathrm{tf} / \mathrm{cm}^{2}, L=30 \mathrm{~cm}$ の場合を除いては定着域が弾塑性状態となるものであ る。

計算結果を図一17 と図一18 に示す。

計算結果は瞬時 $(t=0)$ の鉄筋の抜出し量と,クリー プと乾燥収縮を共に考慮した終局時の鉄筋の抜出し量と について次式で示してある。

$$
\lambda=\frac{\text { 弹塑性解析値 }}{\text { 弹性解析值 }}
$$

図一17 について, 定着長 $L=30 \mathrm{~cm}$ で $\sigma_{50} \leqq 2.5 \mathrm{tf} / \mathrm{cm}$ の場合の終局時に対する $\lambda$ の値は $\lambda=1.0(L=30 \mathrm{~cm}$ で の破線）となったが,これは $t \geqq 1$ (日) 以後の有効定 着域における付着応力ーすべり関係が弾性状態となった ためである。

図一17から次のことがいえる。

両引き試験体の場合定着長 $L$ が長くなると入が大き

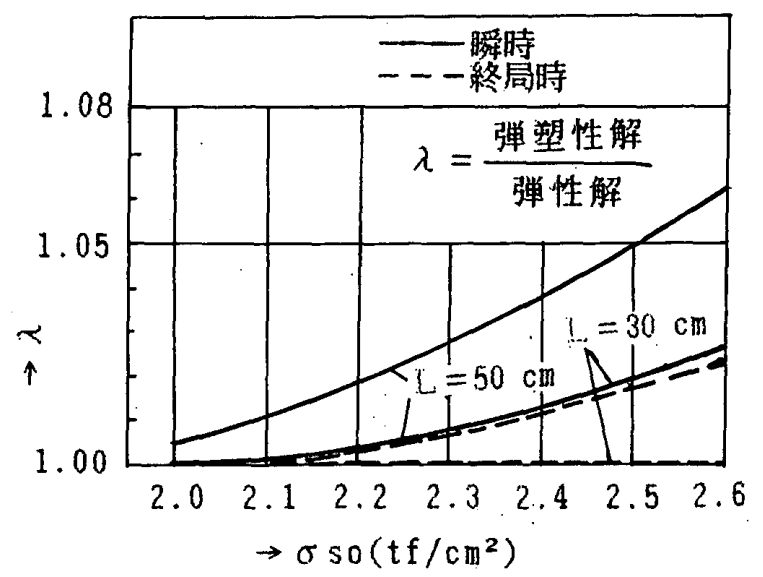

図一17 両引き試験体の鉄笳の抜出し量について弾塑性解之弾 性解の比較 


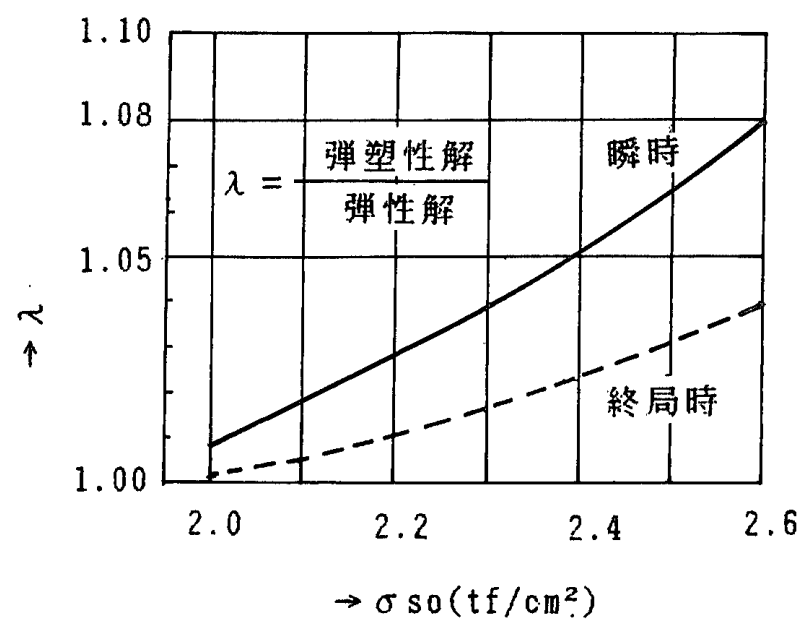

図一18 鉄筋の抜出し量の弾性解と弾塑性解の比較 (片引き式 験体 $L=35 \mathrm{~cm}$ )

くなる。また，終局時よりも瞬時の場合の入の方が高い。 $L=50 \mathrm{~cm}$ で瞬時の場合, 長期設計荷重時引張鉄筋応力 $\left(2.0 \mathrm{tf} / \mathrm{cm}^{2}\right)$ を 3 割上回る応力 $\sigma_{s 0}=2.6 \mathrm{tf} / \mathrm{cm}^{2}$ に対し ても，入はせいぜい 1.06 倍となるにすぎない。

図一18は $L=35 \mathrm{~cm}$ の場合の片引き試験体での $\lambda$ の 変化を示したものであるが, $\sigma_{s 0}=2.4 \mathrm{tf} / \mathrm{cm}^{2}$ 程度以下な らば, $\lambda$ はせいぜい 1.05 以下であり，弾塑性解析值は 弾性解析値の $5 \%$ 以内に収まることが示されている。

以上のことから，通常の RC 造の梁幅程度（40－50 $\mathrm{cm})$ の定着長であるならば，長期設計荷重時引張鉄筋 応力あるいはこれを数割程度上回る鉄筋応力レベルに対 して，瞬時および終局時の鉄筋の拔出し量は弾性解析に よる算定式 (31) 式で十分予測できる。

5-2 梁内に定着したスラブ端部引張鉄筋の計算用定 着長の検討

通常, ひび割れを生じた RC 造スラブの端部引張鉄 筋の抜出し量は梁スタブ部分を片引き試験体にモデル化 して, 梁スタブ部分からの引張鉄筋の抜出し量として算 定する。この場合，小森らの研究国2)では定着長 $L$ は, 実際に梁スタブ部分に埋込まれている鉄筋の定着長を用 いるのではなく，(33）式で計算する。しかる後，鉄筋 の抜出し量 $S_{w}$ は $(34)$ 式から算定している。

$$
\begin{aligned}
& L=\frac{A_{s} \sigma_{s 0}}{\phi \tau_{a v}} \\
& S_{w}=\frac{L \sigma_{s 0}}{2 E_{s}}
\end{aligned}
$$

この両式の欠点は平均付着応力 $\tau_{a v}$ を付着応力性状に 関係なく任意に決定しなければならないことと， $S_{w}$ は $\sigma_{s 0}=$ 一定の場合経時的な拔出し量にならない点にある。 また，（34）式は，理論的には，付着応力分布が均一の 場合, すなわち, 定着域が塑性状態にあるような場合に 適用できるものであり，長期設計荷重レベルに対して妥 当性があるかどうか疑問が残る。

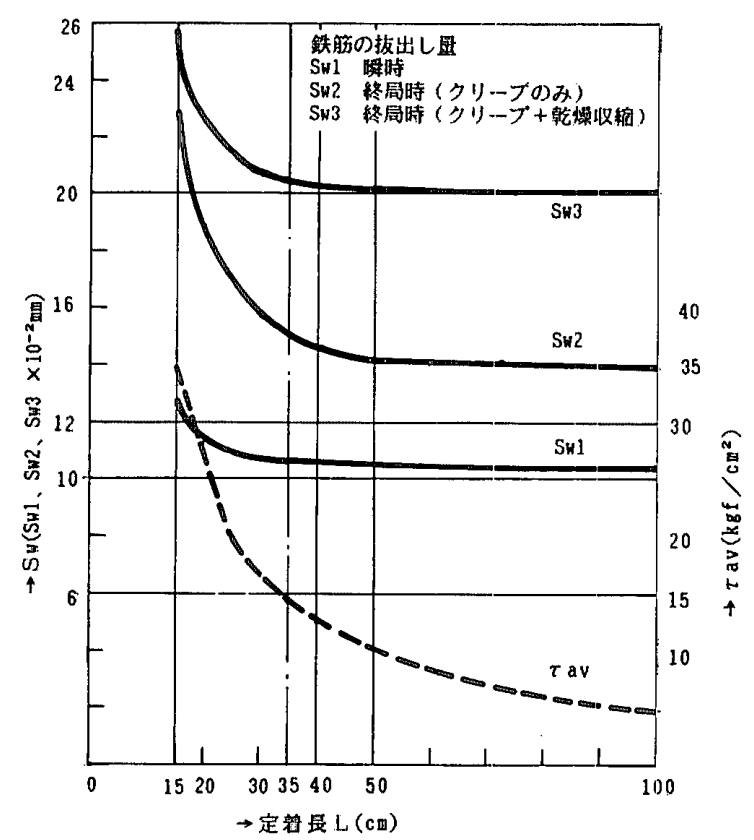

图一19 鉄筋の抜出し量 $S_{w}$ と平均付着忘力 $\tau_{a v}$ (片引き試験体, 弾性解)

そこで, 5-1 で長期設計荷重レベルに対し弾性解と弾 塑性解とはさほど大きく違わないことが示されたので, 弾性解によって，定着長の変化による鉄筋の瞬時抜出し 量, 終局時抜出し量および平均付着応力を検討する。解 析に用いた断面寸法, 鉄筋とコンクリートの材料定数は 表一3のものと同じであるが, 加力応力は $\sigma_{s 0}=2.0$ $\mathrm{tf} / \mathrm{cm}^{2}$ （一定）で，また定着長 $L$ は $15 \mathrm{~cm}$ から $100 \mathrm{~cm}$ まで変化させている。

計算結果を図一19に示す。

この図は，定着長が長くなるほど鉄筋の拔出し量が小 さくなることを示しているが，特に $L=15 \sim 30 \mathrm{~cm}$ に対 し大きく娍少している。 $L=35 d(d$ : 鉄筋直径 $)=35$ $\mathrm{cm}$ に対する鉄筋の抜出し量は， $L=100 \mathrm{~cm}$ に対するも のと比較して, 瞬時および,クリープと乾燥収縮を考虑

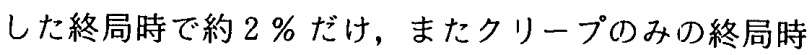
で約 $8 \%$ だけ大きくなっている。

平均付着応力 $\tau_{\alpha v}$ は, 定着長 $L$ が大きくなるにつれて, 大きく減少する。これは， $L$ が大きくなると付着面積 が大きくなる一方で， $\sigma_{s 0}$ が一定であるということから も肯首される。

この図一19 の結果から，長期設計荷重レベル程度の 鉄筋の抜出し量算定に（33）式を適用するのはさほど大 きな理由がなく，むしろ，定着長 $L$ として建築学会 $\mathrm{RC}$ 構造計算規準による $L=35 d^{\text {文13) }}$ を採用した方が簡 単で，より明快であることが分かる。

6. まとめ

(1) 長期設計荷重下のひび割れを生じた RC 造スラ ブについて, 端部引張鉄筋の経時的抜出し量は比較 的簡単な bi-linear 型の付着応力ーすべり関係および 
付着劣化を考虑した本定式化による方法で実用的に 十分算定できる。

(2) 長期設計荷重レベルに対し，鉄筋の抜出し量は弾 性解析によっても十分近似できる。

(3) スラブ端部の引張鉄筋が梁スタブ内に定着されて いる場合, 本解析の範囲内では特に平均付着応力を 与える必要がなく, 定着長 $L$ として $L=35 d(d$ ： 鉄筋直径）を採用して十分である。

\section{謝 辞}

本論文をまとめるにあたって．大林組技術研究所 小 柳光生博士および大阪大学工学部建築工学科助手 大野 義照氏に貴重な資料を提供していただくとともに，種々 の質疑についても貴重な御意見を頂いた。また，長崎大 学構造工学科教授 小森清司博士からも貴重な御助言を 頂いた。ここに厚く御礼を申し上げます。

\section{参考文献}

1）東洋 一，小森清司「鉄筋コンクリート帯スラブの長期 たわみに関する実験的研究（2）」，日本建築学会大会講 演梗概集 (中国)，pp. 1837－1838，昭和 52 年 10 月

2）杉野目章，井野 智ほか「使用荷重下における鉄筋コン クリート床スラブたわみの予測計算」, 日本建築学会構造 系論文報告集, 第 372 号, pp. 103 113, 昭和 62 年 2 月

3）小柳光生著「鉄筋コンクリート床スラブの長期たわみに 関する研究」, 学位論文, 昭和 60 年 11 月

4) 狩野春一，向井 毅「コンクリートと鉄筋の付着クリー プに関する研究（第 1 報）」，日本建築学会論文報告集， 第 89 号, p. 39, 昭和 38 年 9 月

5）小柳光生ほか「RC スラブの長期におけるひびわれ変形 に関する研究 (その 4$)$ )，大林組技術研究所報，No. 19, pp. $64 \sim 68,1979$ 年

6）長滝重義, 佐藤良一「異形鉄筋とコンクリートの付着ク リープ性状」, 第 6 回コンクリート工学講演論文集, pp. 553 556, 1984

7）鈴木計夫，大野義照ほか「持続荷重下における異形鉄筋 とコンクリートの付着特性」, セメント技術年報 40 , pp. $514 \sim 517$, 昭和 61 年

8）鈴木計夫，大野義照ほか「持続荷重下における異形鉄筋 とコンクリートの付着特性」, 日本建築学会近畿支半研究 報告, pp. 85 88, 昭和 60 年 5 月

9）黒正清治，林 静雄ほか「異形鉄筋とコンクリートの付 着に関する基礎的研究（その 2 ひびわれ面からの距離 による付着すべり関係の違い)」, 日本建築学会大会学術 講演梗概集（東北），pp. 1327 1328，昭和 57 年 10 月 10）小阪義雄，森田司郎著「鉄筋コンクリート構造」，p. 52, 丸善, 昭和 50 年

11）六車 熙, 森田司郎「鉄筋コンクリート梁の変形ときれ つ」, 日本建築学会論文報告集, 第 90 号, pp. 13 18, 昭和 38 年 9 月

12）前出文 3 ), p. 161

13）日本建築学会「鉄筋コンクリート構造計算規準・同解説」, p. 237 , 昭和 60 年

14）岩原昭次「付着クリープと鉄筋の抜出しに関する検討（そ の1)，(その2)」，日本建築学会九州支部研究報告, 第 30 号, pp. $277 \sim 284$, 昭和 63 年 3 月

注

注 1) RC 造スラブにおける鉄筋の抜出しとは梁スタブ部分 からのスラブ端部引張鉄筋の経時的な抜出しのことを いい, 固定端位置における鉄筋変位とコンクリート変 位の相対差で表される。一般に, 梁スタブ部分は付着 応力問題における片引き試験体あるいは両引き試験体 のいずれかでモデル化される。この片引き・両引きの 2 つの試験体に対しては，鉄筋の抜出しとは加力端位 㯰における鉄筋とコンクリートの相対すべりをさすこ とになる。すなわち，鉄筋が埋込まれている位置の鉄 筋の抜出し量を $S_{w}$, その位置の鉄筋とコンクリート の変位を $u_{s}, u_{c}$ とするる $S_{w}=u_{s}-u_{c}$ の関係が成立 つ。一方, 両引き試験体に対して, 鉄筋の伸び $\delta$ は $\delta$ $=2 u_{s}$ となる。

注 2)解析用断面の大きさは文 11）の六車・森田の方法にし たがったが，参考として，片引き試験体に対する瞬時 の鉄筋の抜出し量 $S_{0}$ と鉄筋比 $p\left(=A_{s} / A_{c}\right)$ との関係

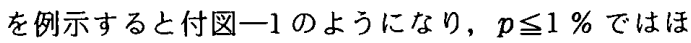
とんど $S_{0}$ は $p$ に関係しないことが分かる。なお，一 点鎖線はコンクリートを判体とした場合の解を示した ものである。

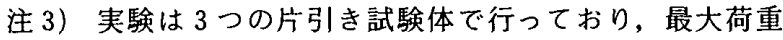
（約 $2.2 \mathrm{tf}$ の引抜力）の半分の大きさの荷重に対する 3 つの試験体の鉄筋の抜出し量の平均は $8.8 \times 10^{-2}$ $\mathrm{mm}$ で, 一方, 同荷重に対する解析値は $8.9 \times 10^{-2} \mathrm{~mm}$ となった。

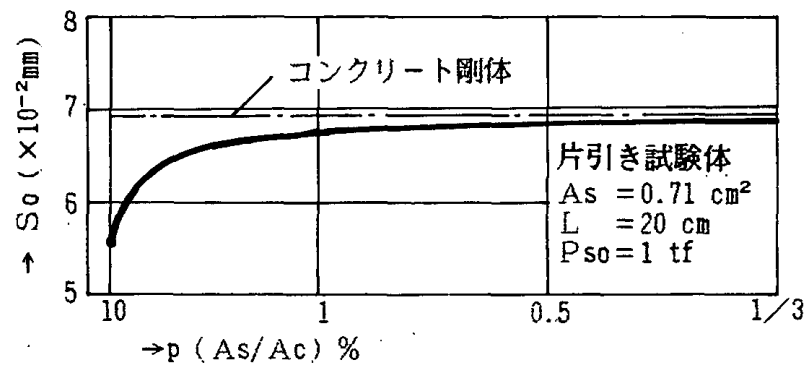

付図一1 鉄筋の抜出し量 $S_{0}$ と鉄筋比 $p(\%)$ 


\section{SYNOPSIS}

UDC : 624. 012. $45: 624.041 .65: 620.191: 624.042 .1$

\section{STUDIES ON SLIPPAGE OF REINFORCING BAR IN REINFORCED CONCRETE SLABS UNDER SUSTAINED DESIGN LOADING}

by Dr. TERUJI IWAHARA, Asso. Prof., Department of Architecture, The Kumamoto Institute of Technology, Member of A.I.J.

As one of the factors which influence long-term deflections on reinforced concrete slabs after being cracked, the slippage of tension steel at fixed edges has been generally accepted.

From previously published test data, it is obvious that the influence on the slippage of tension steel is so large that it can not be disregared when compared with the influence on creep and shrinkage of concrete. However, a method for the quantitative estimation on the change of slippage of tension steel with time is still not clear.

In this paper, the formulation is shown on the basis of bond stress-relative slippage relation and then the validity of this formulation is examined by comparing analayzed results with experimental results.

Finally, even though equations solved by elastic analysis are used as the equation for the calculation of the slippage of tension steel under sustained design loading, it is shown that the analyzed results which are given by these equations are sufficiently useful for structural design when the results of elastic analysis are compared with the results of elastic-plastic analysis. Furthermore, it is shown that $L=35 d$ may be used as the anchorage length in the case of utilizing a calculated equation for the slippage of tension steel on pull-out specimens. 